\title{
Glycerin and cashew and castor oils inclusion in the diets of Purunã bulls finished in feedlot on
}

\section{fatty acid percentage in the Longissimus dorsi}

\author{
Glicerina e inclusão de óleos de caju e mamona na dieta de touros Purunã terminados em \\ confinamento sobre a porcentagem de ácidos graxos no Longissimus dorsi
}

Inclusión de glicerina y aceite de anacardo y ricino en las dietas de toros Purunã terminados en corral de engorde sobre porcentaje de ácidos grasos en el Longissimus dorsi E-mail: eltongbonafe@gmail.com Federal Technological University of Paraná, Brazil Venicio Macedo Carvalho ${ }^{3}$ ORCID: https://orcid.org/0000-0002-2875-7799 State University of Maringá, Brazil E-mail: venicio_@hotmail.com

Ana Carolina Pelaes Vital ${ }^{4}$

ORCID: https://orcid.org/0000-0002-6033-6898 State University of Maringá, Brazil E-mail: ana_carolv@hotmail.com

Mariana Garcia Ornaghi ${ }^{3}$

ORCID: https://orcid.org/0000-0002-2815-3135 State University of Maringá, Brazil

E-mail: mariana.ornaghi@safeeds.com.br

Rodolpho Martin do Prado

ORCID: https://orcid.org/0000-0003-3529-7783 State University of Maringá, Brazil

E-mail: rodolphoprado@hotmail.com. José Luiz Moletta ${ }^{5}$

ORCID: https://orcid.org/0000-0003-4971-2722 Agronomic Institute of Paraná, Brazil E-mail: moletta@pr.gov.br

Ivanor Nunes do Prado 6

ORCID: https://orcid.org/0000-0003-1058-7020 State University of Maringá, Brazil E-mail: inprado@uem.br

\begin{abstract}
This work was carried out to study the glycerin and cashew and castor oils inclusion as natural additives on fatty acid composition of perirenal fat, subcutaneous fat and muscle Longissimus thoracis of Purunã bulls finished in feedlot for 252 days. A total of 32 Purunã bulls (11-12 \pm 2.0 months; $202.8 \pm 14.4 \mathrm{~kg})$ were finished in feedlot with 4 diets $(\mathrm{n}=8)$ : CONT - basal diet; VOIL - basal diet and inclusion of vegetable oils ( $3 \mathrm{~g} / \mathrm{animal} /$ day); GLYC - basal diet and inclusion of glycerin (20.1\% glycerin in DM basis); GLVO - basal diet and inclusion of glycerin (20.1\% glycerin in DM basis) and vegetal oils (3 g/animal/day). Glycerin inclusion reduced SFA, MUFA and PUFA levels in the diets. Glycerin and
\end{abstract}

${ }^{1}$ In memoriam

Ph.D. Department of Animal Science, State University of Maringá, Paraná, Brazil

${ }^{2}$ PhD. Department of Chemistry Graduate Program, Federal Technological University of Paraná, Brazil

${ }^{3}$ Ph.D. Department of Animal Science, State University of Maringá, Paraná, Brazil

${ }^{4}$ Food Science Post-Graduate Program, State University of Maringá, Maringá, Brazil

${ }^{5}$ Ph.D. Research - Department of Animal Science - Agronomic Institute of Paraná, Brazil

${ }^{6}$ Ph.D. Professor - Department of Animal Science - State University of Maringá - 1A - CNPq fellowship, Maringá, Paraná, Brazil 
vegetable oils inclusion in the diets of bulls finished in feedlot did not change $(\mathrm{P}>0.05)$ lauric, myristic, palmitic, docosanoic, n-7-tetradecenoic, palmitoleic, $n$-11 trans-vaccenic, oleic, $n$-7 cis-vaccenic, cis-9, t11 - CLA, n-3 docosapentaenoic and $n-3$ docosahexaenoic fatty acids levels in perirenal fat, subcutaneous fat and Longissimus thoracis muscle of bulls finished in feedlot. However, glycerin inclusion in the diets increased $(\mathrm{P}<0.05)$ pentadecanoic, margaric and $n-9$, cis-10 heptadecanoic fatty acids levels when compared of perirenal fat, subcutaneous fat and Longissimus thoracis muscle of bulls fed CONT and VOIL diets. On the other hand, glycerin inclusion decreased $(\mathrm{P}<0.05)$ linoleic fatty acid in perirenal fat, subcutaneous fat and Longissimus thoracis muscle in comparison of CONT and VOIL diets. Glycerin and vegetables oils inclusion in the diets did not alter $(\mathrm{P}>0.05)$ SFA and MUFA levels in perirenal fat from bulls fed four diets. The PUFA, n-6 and n-3 levels and PUFA:SFA and n-6:n-3 ratios were similar (P > 0.05) between perirenal fat of bulls fed CONT and VOIL diets and greater $(\mathrm{P}<0.05)$ when compared of perirenal fat from bulls fed GLYC and GLVO diets. SFA, MUFA levels and n- 6 and n-3 ratios were similar (P > 0.05) among all diets. PUFA and MUFA levels in fat subcutaneous and n-6:n3 ratio were similar $(\mathrm{P}>0.05)$ between GLYC and GLVO diets, but greater than CONT and GLYC diets. Total fatty acids sum levels in Longissimus thoracis muscle were similar $(\mathrm{P}>0.05)$ among bulls from all diets, except the lowest levels in bulls from GLYC and GLVO diets in comparison to CONT and VOIL diets. In conclusion glycerin inclusion in the diets modifies fatty acids in fat and muscle of bulls finished in feed-lot.

Keywords: Anacardium Acid; Bio-Fuels; Corn Grain; Glycerol; Ricinoleic Acid.

\section{Resumo}

Este trabalho foi realizado com objetivo de estudar a inclusão da glicerina e de óleos de caju e mamona como aditivos naturais na composição de ácidos graxos da gordura perirenal, da gordura subcutânea e do músculo Longissimus thoracis de bovinos não castrados Purunã terminados em confinamento por 252 dias. Um total de 32 animais Purunã (11-12 \pm 2,0 meses; $202,8 \pm 14,4 \mathrm{~kg})$ foram terminados em confinamento com 4 dietas $(\mathrm{n}=8)$ : CONT - dieta basal; VOIL - dieta basal e inclusão de óleos vegetais ( $3 \mathrm{~g} /$ animal / dia); GLYC - dieta basal e inclusão de glicerina (glicerina 20,1\% em base MS); GLVO - dieta basal e inclusão de glicerina (20,1\% glicerina base da MS) e óleos vegetais (3 g/animal / dia). A inclusão de glicerina reduziu ( $\mathrm{P}<0,05)$ os níveis de SFA, MUFA e PUFA nas dietas. A inclusão de glicerina e óleos vegetais nas dietas de touros terminados em confinamento não alterou $(\mathrm{P}>0,05)$ os níveis dos ácidos graxos láurico, mirístico, palmítico, docosanóico, n-7-tetradecenóico, palmitoléico, $n$-11 trans-vacênico, oleico, $n$-7 cis, vaccênico, cis-9, t11 - CLA, $n$-3 docosapentaenóico e $n$-3 docosahexaenóico na gordura perirrenal, gordura subcutânea e músculo Longissimus thoracis de bovinos terminados em confinamento. No entanto, a inclusão de glicerina nas dietas aumentou $(\mathrm{P}<0,05)$ os níveis dos ácidos graxos pentadecanóico, margarico e $n-9$, cis-10 heptadecanóico quando comparados à gordura perirrenal, gordura subcutânea e músculo Longissimus thoracis de bovinos alimentados com as dietas CONT e VOIL. Por outro lado, a inclusão de glicerina diminuiu $(\mathrm{P}<0,05)$ os níveis dos ácidos graxos linoléicos na gordura perirrenal, gordura subcutânea e músculo Longissimus thoracis em comparação com as dietas CONT e VOIL. A inclusão de glicerina e óleos vegetais nas dietas não alterou $(\mathrm{P}>0,05)$ os níveis de SFA e MUFA na gordura perirrenal de bovinos alimentados com as quatro dietas. Os níveis de PUFA, n-6 e n-3 e as razões de PUFA:SFA e n6:n-3 foram semelhantes $(\mathrm{P}>0,05)$ entre a gordura perirrenal de bovinos alimentados com dietas CONT e VOIL e maiores $(\mathrm{P}<0,05)$ quando comparados de gordura perirrenal de bovinos alimentados com dietas GLYC e GLVO. Os níveis de SFA, MUFA e n-6 e n-3 foram semelhantes $(P>0,05)$ entre todas as dietas. Os níveis de PUFA e MUFA na gordura subcutânea e a razão n-6:n3 foram semelhantes $(\mathrm{P}>0,05)$ entre as dietas de GLYC e GLVO, mas maiores do que as dietas de CONT e GLYC. Os níveis da soma dos ácidos graxos totais no músculo Longissimus thoracis foram semelhantes $(\mathrm{P}>0,05)$ entre os bovinos de todas as dietas, exceto os níveis mais baixos nos bovinos das dietas GLYC e GLVO em comparação com as dietas CONT e VOIL. Conclui-se que a inclusão de glicerina nas dietas modifica os níveis de ácidos graxos na gordura e no músculo de bovinos terminados em confinamento.

Palavras-chave: Anacardium Acid; Biocombustíveis; Grão de Milho; Glicerol; Ácido Ricinoléico.

\section{Resumen}

Este trabajo se llevó a cabo para estudiar la inclusión de glicerina y aceite de anacardo y ricino como aditivos naturales en la composición de ácidos grasos de la grasa perirrenal, grasa subcutánea y musculo Longissimus thoracis de toros Purunã terminados en corral de engorde durante 252 días. Un total de 32 toros Purunã (11-12 \pm 2.0 meses; $202.8 \pm 14.4$ $\mathrm{kg}$ ) fueron terminados en corral de engorde con 4 dietas $(\mathrm{n}=8)$ : CONT - dieta basal; VOIL - dieta basal e inclusión de aceites vegetales (3 g/animal / día); GLYC - dieta basal e inclusión de glicerina (20,1\% de glicerina en base MS); GLVO - dieta basal e inclusión de glicerina (20,1\% de glicerina en base MS) y aceites vegetales (3 g/animal/día). La inclusión de glicerina redujo los niveles de SFA, MUFA y PUFA en las dietas. La inclusión de glicerina y aceites vegetales en las dietas de toros terminados en corral de engorde no cambió ( $\mathrm{P}>0.05)$ los niveles de ácidos láurico, mirístico, palmítico, docosanoico, $n$-7-tetradecenoico, palmitoleico, $n$-11 trans-vaccénico, oleico, $n$ - 7 cis, vaccénicos, cis-9, t11-CLA, $n-3$ docosapentaenoico y $n-3$ docosahexaenoico en la grasa perirrenal, grasa subcutánea y músculo Longissimus thoracis de toros terminados en corral de engorde. Sin embargo, la inclusión de glicerina en las dietas aumentó $(\mathrm{P}<0.05)$ los niveles de los ácidos grasos pentadecanoico, margárico y heptadecanoico n-9, cis-10 en comparación con la grasa perirrenal, la grasa subcutánea y el músculo Longissimus thoracis de toros alimentados con dietas CONT y VOIL. Por otro lado, la inclusión de glicerina disminuyó $(\mathrm{P}<0,05)$ los niveles de los ácidos grasos linoleicos en la grasa perirrenal, la grasa subcutánea y el músculo Longissimus thoracis en comparación con las dietas 
CONT y VOIL. La inclusión de glicerina y aceites vegetales en las dietas no alteró (P>0.05) los niveles de SFA y MUFA en la grasa perirrenal de toros alimentados con las cuatro dietas. Los niveles de PUFA, n-6 y n-3 y las proporciones de PUFA: SFA y n-6: n-3 fueron similares $(\mathrm{P}>0.05)$ entre la grasa perirrenal de los toros alimentados con dietas CONT y VOIL y mayores $(\mathrm{P}<0.05)$ en comparación de grasa perirrenal de toros alimentados con dietas GLYC y GLVO. Los niveles de SFA, MUFA y las proporciones n-6 y n-3 fueron similares (P > 0.05) entre todas las dietas. Los niveles de PUFA y MUFA en la grasa subcutánea y la relación n-6: n3 fueron similares $(\mathrm{P}>0.05)$ entre las dietas GLYC y GLVO, pero mayores que las dietas CONT y GLYC. Los niveles de la suma de ácidos grasos totales en el músculo Longissimus thoracis fueron similares $(\mathrm{P}>0.05)$ entre los toros de todas las dietas, excepto los niveles más bajos en los toros de las dietas GLYC y GLVO en comparación con las dietas CONT y VOIL. En conclusión, la inclusión de glicerina en las dietas modifica la composición de los ácidos grasos en la grasa y el músculo de los toros terminados en el pienso.

Palabras clave: Anacardium Acid; Biocombustibles; Grano de Maíz; Glicerol; Ácido Ricinoleico.

\section{Introduction}

Fat is important nutrient in the diet, improves palatability food, increases vitamins and carotenoids absorption. However, high intakes of saturated fats are a risk factor for several chronic diseases, such as cardiovascular disease, obesity, diabetes and cancer. According HMSO (1994) to adequate food, the daily intake of fat should not exceed $35 \%$ of the total diet from different food sources. In Brazil, red meat has an important nutritional value in human diet (Eiras et al., 2017; Guerrero et al., 2018; Vital et al., 2018). In recent year's research on livestock production are concerned to improve meat quality (Cruz et al., 2014; Eiras et al., 2014b; Monteschio et al., 2017; Valero et al., 2014). However, its demand high investments, technology and alternatives feed (Rotta et al., 2009).

Crude glycerin is an excellent energy source by corn partial replacing in the diets for beef cattle (Cruz et al., 2014; Eiras et al., 2014a; Eiras et al., 2014b; Françozo et al., 2013). In metabolism animal, glycerol increases in the gluconeogenesis which improve synthesis of glucose in the liver. Furthermore, provide energy for cellular metabolism and increase fat deposition. Red meat has high fatty acids saturated contents (Prado et al., 2008, 2009; Rotta et al., 2009). In general, fatty acids polyunsaturated food contents is extensively metabolized by microorganisms and bio-hydrogenated which resulting in stearic acid production (Wu \& Palmquist, 1991) and deposition on and into muscle.

Other products are widely researched around the world in order to improve ruminal parameters and decrease fatty acids saturated production. According Cruz et al. (2014) and Valero et al. (2016) the association of the compounds extracted from cashew and castor oils, the similar effects were observed in comparison the sodium monensin. Essential oils contain secondary metabolites (terpenoids and phenolic compounds) that confer antimicrobial action on gram-positive and gram-negative bacteria (Benchaar et al., 2008). Cashew and castor oil contain high percentage of compounds whit characteristics that confer antimicrobial action. Previous studies reported antimicrobial action is attributed by interacting of compounds with the bacteria cell membrane, such ion gradients, electron transport, protein translocation, phosphorylation and enzyme-dependent reactions (Benchaar et al., 2008; Ultee et al., 2000). Castor oil contain high percentage of ricinoleic acid, which confer antimicrobial properties; whereas, cashew contain high percentage of anacardic acid and lower proportion cardol and cardanol acids. These compounds in cashew confers antibacterial, antioxidant and anti-parasitic (Kubo et al., 1999) activities. Previous studies reported by Ultee et al. (2000) show that synergisms between compounds extracted from different products increase antibacterial activity. Thus, the synergism between compounds in cashew and castor oils may improve the antimicrobial effect on microorganisms. However, the results are unclear on fatty acids contents in the meat.

This study was realized to evaluate corn grain replacing by glycerin with $812 \mathrm{~g}$ of glycerol per $\mathrm{kg} / \mathrm{DM}$ contained, and vegetal oils from cashew and castor oils extract produced in northern Brazil on fatty acids composition in fat perirenal, fat subcutaneous and in Longissimus thoracis muscle of Purunã young bulls finished in feedlot for 252 days. 


\section{Material and methods}

\subsection{Ethic committee, Local, animals, diets and experimental design}

The present experiment was approved by the Department of Animal Science of the State University of Maringá and performed at the Experimental Farm of the Agronomic Institute of Paraná, Ponta Grossa city, Paraná state, Brazil south, and followed the guidelines of biomedical research with animals (CIOMS/OMS, 1985) (Protocol - 550.891-2010-2/CNPq).

Thirty-two Purunã young bulls (1/4 Aberdeen Angus + 1/4 Caracu + 1/4 Charolais + 1/4 Canchim) were selected at birth and assigned according the body weight into individual pens $\left(8 \mathrm{~m}^{2}\right.$ for each animal) with $2062.8 \pm 14.4 \mathrm{~kg}$.

Experimental design was composited of four treatments: CONT - diet without glycerin; VOIL - diet with cashew and castor oils (3 g/animal/day); GLYC - diet with glycerin (20.1\% glycerin in DM basis), and GLVO - diet with glycerin (20.1\% glycerin in DM basis and vegetal oils - 3 g/animal/day). Each experimental treatment comprised 8 Purunã young bulls. It was performed an adaption period for 21 days and during time which the bulls were fed corn silage and concentrate (40:60 ratio, respectively). Concentrate base containing soybean meal, corn grain and mineral salt ad libitum. The bulls were given access to a diet formulated provide a weight gain of $1.0 \mathrm{~kg} /$ day and meet requirements for fattening beef cattle.

The feeds were offered half in the morning at $0800 \mathrm{~h}$ and half in the afternoon at $1500 \mathrm{~h}$. The concentrate intake was fixed in BW 1.4\% adjusted at the 28-d. Samples of offered corn silage, concentrate was collected twice weekly for estimations of $\mathrm{DM} \%$.

The glycerin was produced in a soy-diesel facility and the chemical composition was determined in an Institute of Technology of Paraná. Glycerin contained (g/kg, as-fed) 23.2 water, 4.76 ashes, 812 glycerol, $11.63 \mathrm{Na}$ and (mg/kg, as-fed) 3.3 methanol, 79.1 k, 35.8 Cl, 16.3 Mg, 239 P, and 3.65 Mcal/kg of crude energy. Glycerin feed in the current study was used as an energetic ingredient; therefore, to obtain four isoenergetic diets, the glycerin level was counterbalanced, mainly by a decrease in corn grain content (Table 1). The vegetal oils contain ricinoleic acid, anacardic acid, cardanol and cardol. Ricinoleic acid was obtained from castor oil (extracted from castor seed) and anacardic acid, cardanol and cardol from the cashew both were produced in northern Brazil. Vermiculite was used for solidification of vegetal oils. The mix of vegetal oils was realized in Laboratory of analysis Oligo Basics Agroindustrial Ltda. It was used $3 \mathrm{~g} / \mathrm{animal} /$ day. All diets were formulated to be isonitrogenous (Table 2). Water and mineral salt were given ad libitum. Mineral salt contained (g/kg; as-fed) $150 \mathrm{Ca}, 88 \mathrm{P}, 0.08 \mathrm{Co}, 1.45 \mathrm{Cu}, 10 \mathrm{~S}, 1.0 \mathrm{Fe}$, 0.88 F, 0.06 I, $10 \mathrm{Mg}, 1.1 \mathrm{Mn}, 0.02 \mathrm{Se}, 120 \mathrm{Na}$ and $3.40 \mathrm{Zn}$.

Table 1. Ingredients and percentage of the basal diets.

\begin{tabular}{lcccc}
\hline \multirow{2}{*}{ Ingredients, $\%$} & \multicolumn{3}{c}{ Diets, g/kg of DM } \\
\cline { 2 - 5 } & $\mathrm{CONT}^{1}$ & $\mathrm{VOIL}^{2}$ & $\mathrm{GLYC}^{3}$ & $\mathrm{GLVO}^{4}$ \\
\hline Corn silage & 420 & 420 & 420 & 420 \\
Soybean meal & 103 & 103 & 150 & 150 \\
Corn grain & 477 & 447 & 227 & 197 \\
Glycerin & & & 203 & 203 \\
Vegetable oils & & 30 & 30 \\
\hline
\end{tabular}

${ }^{1} \mathrm{CONT}$ - Without glycerin or vegetable oils. ${ }^{2}$ VOIL - Vegetable oils. ${ }^{3} \mathrm{GILYC}$ - Glycerin. ${ }^{4} \mathrm{GLVO}$ - Glycerin + vegetable oils. Source: Authors. 
Table 2. Chemical composition of the basal diets (DM, \% $)^{1}$.

\begin{tabular}{lccccccccccc}
\hline Ingredients & $\mathrm{DM}^{2}$ & $\mathrm{OM}^{3}$ & $\mathrm{Ash}$ & $\mathrm{CP}^{4}$ & $\mathrm{EE}^{5}$ & $\mathrm{NDF}^{6}$ & $\mathrm{ADF}^{7}$ & $\mathrm{NNE}^{8}$ & $\mathrm{TDN}^{9}$ & $\mathrm{DE}^{10^{*}}$ & $\mathrm{ME}^{11^{*}}$ \\
\hline Corn silage & 28.9 & 99.0 & 0.97 & 5.79 & 2.07 & 42.8 & 21.6 & 73.8 & 64.7 & 2.85 & 2.34 \\
Corn grains & 89.4 & 99.0 & 0.99 & 7.43 & 4.66 & 17.3 & 2.28 & 85.1 & 83.1 & 3.66 & 3.00 \\
Soybean meal & 91.6 & 99.0 & 0.94 & 45.0 & 2.63 & 18.1 & 8.23 & 44.8 & 86.4 & 3.81 & 3.13 \\
Glycerin & 94.2 & 95.2 & 4.76 & 0.07 & 0.12 & & & 95.0 & 80.6 & 3.55 & 2.91 \\
\hline Total diet & & & & & & & & & & & \\
\hline CONT $^{12}$ & 52.1 & 99.0 & 0.98 & 10.6 & 3.36 & 28.1 & 11.0 & 76.2 & 75.6 & 3.34 & 2.74 \\
VOIL $^{13}$ & 52.1 & 99.0 & 0.98 & 10.6 & 3.36 & 28.1 & 11.0 & 76.2 & 75.6 & 3.34 & 2.74 \\
GLYC $^{14}$ & 51.8 & 98.2 & 1.76 & 10.6 & 2.33 & 24.5 & 10.7 & 76.6 & 75.3 & 3.32 & 2.72 \\
GLVO $^{15}$ & 51.8 & 98.2 & 1.76 & 10.6 & 2.33 & 24.5 & 10.7 & 76.6 & 75.3 & 3.32 & 2.72 \\
\hline
\end{tabular}

${ }^{1}$ Analyses conducted by Chemical Laboratory of State University of Maringá. ${ }^{2}$ Dry matter. ${ }^{3}$ Organic matter. ${ }^{4}$ Crude protein. ${ }^{5}$ Ether extract. ${ }^{7}$ Neutral detergent fiber. ${ }^{8}$ Acid detergent fiber. ${ }^{9}$ Total digestible nutrients. ${ }^{10}$ Digestible energy. ${ }^{11}$ Metabolizable energy. ${ }^{*} \mathrm{Mcal} / \mathrm{kg} .{ }^{12} \mathrm{CONT}-$ without glycerin or vegetable oils. ${ }^{13}$ VOIL - Vegetable oils. ${ }^{14} \mathrm{GLYC}$ - Glycerin. ${ }^{15} \mathrm{GLVO}$ - Glycerin + vegetable oils.

Source: Authors.

\subsection{Performance and carcass characteristics}

The animals were weighed at the beginning of the experiment and then every twenty-eight days after a fasting from solid food period of 16 hours, until the end of the experiment (252 days), in order to determine animal performance and carcass characteristics.

Table 3. Fatty acid composition of the diet ingredients fed.

\begin{tabular}{|c|c|c|c|c|c|c|c|c|c|c|}
\hline \multirow{2}{*}{ Item } & \multicolumn{10}{|c|}{ Fatty acid, \% } \\
\hline & $14: 0$ & $16: 0$ & $16: 1 n-9$ & 18:0 & $18: 1 n-9 \mathrm{c}$ & $18: 2 n-6 c$ & $18: 3 n-3$ & AGS & AGMI & AGPI \\
\hline Corn silage & 0.86 & 18.8 & 0.39 & 0.62 & 29.6 & 43.9 & 5.66 & 20.3 & 30.1 & 49.5 \\
\hline Soybean oil & 0.11 & 21.1 & 0.10 & 4.28 & 15.1 & 53.7 & 5.40 & 25.5 & 15.2 & 59.2 \\
\hline $\begin{array}{l}\text { Corn grain } \\
\text { Glycerin }\end{array}$ & 0.04 & 11.6 & 0.15 & 1.95 & 34.6 & 50.6 & 0.97 & 13.6 & 34.7 & 51.6 \\
\hline \multicolumn{11}{|l|}{ Total diet } \\
\hline $\mathrm{CONT}^{1}$ & 0.39 & 15.6 & 0.25 & 1.63 & 30.5 & 48.1 & 3.40 & 17.6 & 30.7 & 51.5 \\
\hline VOIL $^{2}$ & 0.39 & 15.6 & 0.25 & 1.63 & 30.5 & 48.1 & 3.40 & 17.6 & 30.7 & 51.5 \\
\hline GLYC $^{3}$ & 0.39 & 13.6 & 0.21 & 1.32 & 22.5 & 37.7 & 3.38 & 15.3 & 22.7 & 41.1 \\
\hline $\mathrm{GLVO}^{4}$ & 0.39 & 13.6 & 0.21 & 1.32 & 22.5 & 37.7 & 3.38 & 15.3 & 22.7 & 41.1 \\
\hline
\end{tabular}

${ }^{1} \mathrm{CONT}$ - Without glycerin or vegetable oils. ${ }^{2} \mathrm{VOIL}$ - Vegetable oils. ${ }^{3}$ GILYC - Glycerin. ${ }^{4} \mathrm{GLVO}$ - Glycerin + vegetable oils. Source: Authors.

\subsection{Sampling}

The bulls were slaughtered at a commercial slaughterhouse $10 \mathrm{~km}$ from Ponta Grossa Research Farm, with the same age $(20 \pm 2$ months) according to industrial practices in Brazil, when the bulls reached a final BW of $468.4 \pm 31.5 \mathrm{~kg}$.

At slaughter perirenal fat samples was separated and frozen at $-20^{\circ} \mathrm{C}$ for later analysis. After chilling $\left(24 \mathrm{~h}\right.$ at $\left.4^{\circ} \mathrm{C}\right)$, the right part of the carcass was used to determine the quantitative and qualitative characteristics of LT. Perirenal fat, fat subcutaneous and LT samples were taken by complete cross-section between the $12^{\text {th }}$ and $13^{\text {th }}$ ribs and were immediately taken to the laboratory. From LT samples, fat subcutaneous was separated and the muscle and fat portions were frozen at $-20^{\circ} \mathrm{C}$ for later analysis.

\subsection{Extraction and preparation of fatty acid methyl ester}

Total lipids were extracted with a chloroform/methanol (2:2:1.8 v/v/v) mixture. Fatty acid methyl esters (FAME) were prepared by triacylglycerol methylation. After that, the esters were extracted with $2 \mathrm{~mL}$ of $n$-heptane and freeze stored at $-18^{\circ} \mathrm{C}$ for later chromatographic analysis. 


\subsection{Chromatographic analysis}

Methyl ester was separated by gas chromatography using a Thermo 3300 gas chromatograph fitted with a flame ionization detector (FID) and a CP-7420 fused-silica capillary column ( $100 \mathrm{~m}$ x $0.25 \mathrm{~mm}$ i.d. x $0.25 \mu \mathrm{m}$ of cyanopropyl, SELECT FAME). The operation parameters were as follows: detector temperature $240^{\circ} \mathrm{C}$, injection port temperature $230^{\circ} \mathrm{C}$, column temperature $165^{\circ} \mathrm{C}$ for $18 \mathrm{~min}$, programmed to increase at $4^{\circ} \mathrm{C} \mathrm{min}^{-1}$ up to $235^{\circ} \mathrm{C}$, with final holding time of $14.5 \mathrm{~min}$, carrier gas, hydrogen at $1.2 \mathrm{~mL} \mathrm{~min}^{-1}$, nitrogen makeup gas at $30 \mathrm{~mL} \mathrm{~min}^{-1}$, split injection at 1:80 ratio. For identification, the retention times of the fatty acids were compared to those of standard methyl esters (Sigma, St. Louis, MO). Retention times and peak area percentages were automatically computed with Software Chronquest 5.0. The fatty acid composition on perirenal fat, Longissimus thoracis muscle and fat thickness were expressed as percentage.

\subsection{Enzyme activities $\Delta 9$ desaturase}

The $\Delta 9$ desaturase index for C16 and C18 was calculated as C16 $=100[16: 1 n-9 /(16: 0+16: 1 n-9)]$ and $\mathrm{C} 18=100[18: 1 n$ 9/(18:0+18:1n-9)] (Malau-Aduli et al., 1997). The $\Delta 9$ desaturase index for $\mathrm{C} 16$ calculates the proportion of palmitate (16:0) that is converted to palmitoleate (16:1n-9) and for C18 the proportion of stearase (18:0) that is converted to oleate (18:1n-9), respectively when double bond is inserted by $\Delta 9$ desaturase enzyme. The index elongase enzyme activity (EA) was calculated as $\mathrm{EA}=100(18: 0+18: 1 n-9 / 16: 0+16: 1 n-9+18: 0+18: 1 n-9)$ (Malau-Aduli et al., 1997). The index EA uses all of the nonessential $\mathrm{C} 18$ fatty acids as a proportion of both $\mathrm{C} 16$ and $\mathrm{C} 18$ fatty acids expressed as percentage.

\subsection{Statistical analysis}

The experimental design was completely randomized, with four diets and eight replicates. All variables were submitted to a normality test using the Univariate procedure of SAS (Version 9.1.2, SAS Institute; Cary, NC, USA). The variables were tested for conformity to normal distributions using the Shapiro-Wilk test at $\mathrm{W}>0.90$. Data were analyzed using the MIXED procedure of SAS (Version 9.1.2, SAS Institute). The model statement contained the fixed effect of diet. Data were analyzed using bull as the random variable. Results are reported as least-squares means and were separated using PDIFF. Significance was set at $\mathrm{P}<0.05$.

\section{Results}

\subsection{Fatty acid composition in the perirenal fat}

The levels of lauric $(12: 0 ; 0.03 \% ; \mathrm{P}>0.42)$, myristic $(14: 0 ; 3.29 \% ; \mathrm{P}>0.20)$, palmitic $(16: 0 ; 26.4 \% ; \mathrm{P}>0.09)$, docosanoic (22:0; 0.11\%; P > 0.11), palmitoleic (16:1n-9; 1.71\%; P > 0.15), trans-vaccenic (18:1 t11;2.60\%; P > 0.27), oleic (18:1n-9; 28.4\%; P > 0.37), cis-vaccenic (18:1n-7; 0.59\%; P > 0.45), conjugated linoleic acid (18:2 c9, t11, CLA 0.08\%; P > 0.13), $\gamma$-linolenic (18:3n-6; 0.12\%; $\mathrm{P}>0.15)$, arachidonic (20:4n-6, 0.13\%; $\mathrm{P}>0.21)$, eicosapentaenoic - EPA, 0.14\%, $\mathrm{P}>0.06$, docosapentaenoic - DPA (22:5n-3; 0.06\%; P > 0.11), docosahexaenoic - DHA (22:6n-3; 0.11\%; P > 0.74) fatty acids in the perirenal fat did not change by feeding diets (Table 4). 
Table 4. Fatty acid composition in the perirenal fat of Purunã bulls finished in feedlot.

\begin{tabular}{|c|c|c|c|c|c|c|}
\hline \multirow{2}{*}{ Fatty acids } & \multicolumn{4}{|c|}{ Treatments } & \multirow{2}{*}{$\mathrm{STD}^{5}$} & \multirow{2}{*}{$\mathrm{P}^{6}$} \\
\hline & $\mathrm{CONT}^{1}$ & VOIL $^{2}$ & $\mathrm{GLYC}^{3}$ & $\mathrm{GLVO}^{4}$ & & \\
\hline 12:0, lauric & 0.03 & 0.04 & 0.03 & 0.03 & 0.02 & 0.42 \\
\hline 14:0, myristic & 3.18 & 2.92 & 3.47 & 3.60 & 0.12 & 0.20 \\
\hline 15:0, pentadecanoic & $0.40 \mathrm{~b}$ & $0.39 \mathrm{~b}$ & $0.55 \mathrm{a}$ & $0.55 \mathrm{a}$ & 0.02 & 0.02 \\
\hline 16:0, palmitic & 26.1 & 25.2 & 26.4 & 28.1 & 0.43 & 0.09 \\
\hline 17:0, margaric & $1.04 \mathrm{~b}$ & $1.17 \mathrm{~b}$ & $1.66 \mathrm{a}$ & $1.51 \mathrm{a}$ & 0.06 & 0.01 \\
\hline $18: 0$, stearic & $32.1 \mathrm{a}$ & $34.3 \mathrm{a}$ & $30.6 b$ & $29.5 b$ & 0.54 & 0.07 \\
\hline 22:0, docosanoic & 0.11 & 0.11 & 0.11 & 0.11 & 0.06 & 0.11 \\
\hline $14: 1 n$-7, 7-Tetradecenoic & 0.21 & 0.23 & 0.24 & 0.24 & 0.01 & 0.11 \\
\hline $15: 1 n-9$, pentadecanoic & $0.30 \mathrm{a}$ & $0.28 \mathrm{a}$ & $0.23 b$ & $0.24 b$ & 0.09 & 0.03 \\
\hline $16: 1 n-9$, palmitoleic & 1.69 & 1.54 & 1.76 & 1.83 & 0.04 & 0.15 \\
\hline 17:1 n-9, cis-10-heptadecaenoic & $0.30 \mathrm{~b}$ & $0.31 \mathrm{~b}$ & $0.51 \mathrm{a}$ & $0.45 \mathrm{a}$ & 0.02 & 0.02 \\
\hline 18:1 n-11t, trans-vaccenic & 2.60 & 2.85 & 2.21 & 2.79 & 0.12 & 0.27 \\
\hline $18: 1 n-9 \mathrm{c}$, oleic & 28.6 & 27.3 & 29.5 & 28.4 & 0.42 & 0.37 \\
\hline $18: 1 n-7 \mathrm{c}$, cis-vaccenic & 0.49 & 0.59 & 0.64 & 0.64 & 0.03 & 0.45 \\
\hline 18:2 n-6, linoleic -LA & $2.06 \mathrm{a}$ & $2.01 \mathrm{a}$ & $1.35 b$ & $1.20 \mathrm{~b}$ & 0.09 & 0.01 \\
\hline $18: 2 \mathrm{c} 9, \mathrm{t} 11-\mathrm{CLA}$ & 0.07 & 0.07 & 0.08 & 0.08 & 0.02 & 0.13 \\
\hline $18: 3 n-6, \gamma$-linolenic & 0.13 & 0.12 & 0.12 & 0.11 & 0.02 & 0.15 \\
\hline $18: 3 n$-3, $\alpha$-linolenic - LNA & $0.13 \mathrm{a}$ & $0.11 \mathrm{a}$ & $0.08 b$ & $0.09 \mathrm{~b}$ & 0.05 & 0.05 \\
\hline 20:4 n-6, arachidonic - AA & 0.12 & 0.12 & 0.12 & 0.14 & 0.01 & 0.21 \\
\hline 20:5 n-3, eicosapentaenoic - EPA & 0.14 & 0.15 & 0.14 & 0.13 & 0.01 & 0.06 \\
\hline 22:5 n-3, docosapentaenoic - DPA & 0.05 & 0.06 & 0.05 & 0.07 & 0.05 & 0.11 \\
\hline 22:6n-3, docosahexaenoic - DHA & 0.11 & 0.11 & 0.11 & 0.11 & 0.09 & 0.74 \\
\hline \multicolumn{7}{|l|}{ Total fatty acid sum } \\
\hline Saturated, SFA & 62.9 & 64.1 & 62.8 & 63.4 & 0.43 & 0.72 \\
\hline Monounsaturated, MUFA & 34.1 & 33.0 & 35.1 & 34.5 & 0.45 & 0.49 \\
\hline Polyunsaturated, PUFA & $2.87 \mathrm{a}$ & $2.80 \mathrm{a}$ & $2.11 \mathrm{~b}$ & $1.97 \mathrm{~b}$ & 0.09 & 0.01 \\
\hline$n-6$, omega -6 & $2.31 \mathrm{a}$ & $2.25 \mathrm{a}$ & $1.59 \mathrm{~b}$ & $1.44 \mathrm{~b}$ & 0.09 & 0.01 \\
\hline$n-3$, omega -3 & $0.48 \mathrm{a}$ & $0.48 \mathrm{a}$ & $0.44 b$ & $0.45 b$ & 0.06 & 0.05 \\
\hline PUFA:SFA & $0.05 \mathrm{a}$ & $0.04 \mathrm{a}$ & $0.03 b$ & $0.03 \mathrm{~b}$ & 0.01 & 0.03 \\
\hline$n-6: n-3$ & $4.78 \mathrm{a}$ & $4.67 \mathrm{a}$ & $3.59 \mathrm{~b}$ & 3.19 & 0.34 & 0.05 \\
\hline \multicolumn{7}{|l|}{ Enzymes activities } \\
\hline$\Delta 9$-desaturase $(16)^{\mathrm{A}}$ & 6.09 & 5.79 & 6.27 & 6.10 & 0.13 & 0.68 \\
\hline$\Delta 9$-desaturase $(18)^{\mathrm{B}}$ & 47.1 & 44.2 & 48.9 & 49.0 & 0.69 & 0.04 \\
\hline Elongase $^{\mathrm{C}}$ & 68.5 & 69.7 & 68.1 & 65.9 & 0.53 & 0.07 \\
\hline
\end{tabular}

${ }^{1} \mathrm{CONT}$ - Without glycerin or vegetable oils. ${ }^{2}$ VOIL - Vegetable oils. ${ }^{3}$ GILYC - Glycerin. ${ }^{4}$ GLVO - Glycerin + vegetable oils. ${ }^{5}$ Standard deviation. ${ }^{6}$ Probability of Tukey test for treatment, $\mathrm{n}=8$ per treatment. ${ }^{\mathrm{A}} \Delta 9$-desaturase $(16)=$ index of desaturase enzyme activity in $\mathrm{C} 16$ fatty acids $=100\left(16: 1 \Delta^{9} / 16: 0+16: 1 \Delta^{9}\right) .{ }^{\mathrm{B}} \Delta 9$-desaturase $(16)=$ index of desaturase enzyme activity in C18 fatty acids $=100\left(18: 1 \Delta^{9} / 18: 0+\right.$ 18:1 $\left.\Delta^{9}\right)$. ${ }^{\mathrm{C}}$ Index of elongase enzyme activity in the chain-lengthening of C16-C18 fatty acids $=100\left(18: 0+18: 1 \Delta^{9} / 16: 0+16: 1 \Delta^{9}+18: 0+\right.$ 18:1 $\left.\Delta^{9}\right)$. Total SFA sum of $(\mathrm{C} 12: 0+\mathrm{C} 13: 0+\mathrm{C} 14: 0+\mathrm{C} 15: 0+\mathrm{C} 16: 0+\mathrm{C} 17: 0+\mathrm{C} 18: 0+\mathrm{C} 20: 0+\mathrm{C} 21: 0+\mathrm{C} 22: 0)$. Total MUFA sum of $(\mathrm{C} 14: 1 n-7+\mathrm{C} 15: n-9+\mathrm{C} 16: 1 n-9+\mathrm{C} 16: 1 n-7+17: 1 n-9+\mathrm{C} 18: 1 n-11 \mathrm{t}+\mathrm{C} 18: 1 n-9 \mathrm{c}+\mathrm{C} 18: 1 n-7 \mathrm{c})$. Total $n-6$ sum of $(\mathrm{C} 18: 2 n-6+\mathrm{C} 18: 3 n-$ $6+\mathrm{C} 20: 4 n-6)$. Total $n-3$ sum of (C18:3n-3 + C20:5 n-3 + C22:5 n-3 + C22:6n-3).

Source: Authors.

The glycerin inclusion (GLYC and GLVO diets) increased $(\mathrm{P}<0.02 ;+39 \%)$ the pentadecanoic $(15: 0)$ fatty acid percentage in the perirenal fat in comparison to bulls fed CONT and VOIL diets (Table 4). Still, the pentadecanoic fatty acid percentages were similar $(\mathrm{P}>0.05)$ between perirenal fat of bulls finished with CONT and VOIL diets and GLYC and GLVO diets.

The glycerin inclusion in the diets (GLYC and GLVO diets) increased ( $\mathrm{P}<0.01 ;+35 \%)$ the margaric (17:0) fatty acid percentage in the perirenal fat in comparison to bulls fed CONT and VOIL diets (Table 4). Still, the margaric fatty acid percentages were similar $(\mathrm{P}>0.05)$ between perirenal fat of bulls finished with CONT and VOIL diets and GLYC and GLVO diets. 
The glycerin inclusion in the diets (GLYC and GLVO diets) decreased ( $\mathrm{P}<0.05 ;-11 \%)$ the stearic (18:0) fatty acid percentage in the perirenal fat in comparison to bulls fed CONT and VOIL diets (Table 4). Still, the stearic fatty acid percentages were similar $(\mathrm{P}>0.05)$ between perirenal fat of bulls finished with CONT and VOIL diets and GLYC and GLVO diets.

The tetradecenoic (14:1 $\mathrm{n}-7)$ fatty acid percentage was lower $(\mathrm{P}<0.01 ;-77 \%)$ in the perirenal fat of bulls finished with VOIL diet in comparison of bulls finished with others three diets (Table 4). However, the tetradecenoic fatty acid percentage was similar $(\mathrm{P}>0.05)$ in the perirenal fat of bulls finished with CONT, GLY and GLVO diets.

The glycerin inclusion in the diets (GLYC and GLVO diets) decreased $(\mathrm{P}<0.03 ;-23 \%)$ the pentadecanoic $(15: 1 \mathrm{n}-9)$ fatty acid percentage in the perirenal fat in comparison to bulls fed CONT and VOIL diets (Table 4). Still, the pentadecanoic fatty acid percentages were similar $(\mathrm{P}>0.05)$ between perirenal fat of bulls finished with CONT and VOIL diets and GLYC and GLVO diets.

The glycerin inclusion in the diets (GLYC and GLVO diets) increased $(\mathrm{P}<0.02 ;+57 \%)$ the heptadecanoic $(17: 1 \mathrm{n}-9$, cis-10) fatty acid percentage in the perirenal fat in comparison to bulls fed CONT and VOIL diets (Table 4). Still, the pentadecanoic fatty acid percentages were similar $(\mathrm{P}>0.05)$ between perirenal fat of bulls finished with CONT and VOIL diets and GLYC and GLVO diets.

The glycerin inclusion in the diets (GLYC and GLVO diets) decreased ( $\mathrm{P}<0.03 ;-60 \%)$ the linoleic - LA (17:2 n-6) fatty acid percentage in the perirenal fat in comparison to bulls fed CONT and VOIL diets (Table 4). Still, the linoleic fatty acid percentages were similar ( $\mathrm{P}>0.05)$ between perirenal fat of bulls finished with CONT and VOIL diets and GLYC and GLVO diets.

The glycerin inclusion in the diets (GLYC and GLVO diets) decreased (P $<0.05 ;-41 \%)$ the $\alpha$-linolenic - LNA $(18: 3$ n-3) fatty acid percentage in the perirenal fat in comparison to bulls fed CONT and VOIL diets (Table 4). Still, the $\alpha$-linolenic fatty acid percentages were similar $(\mathrm{P}>0.05)$ between perirenal fat of bulls finished with CONT and VOIL diets and GLYC and GLVO diets.

The $\Delta^{9}$-desaturase $(\mathrm{C} 16)$, The $\Delta^{9}$-desaturase $(\mathrm{C} 18)$ and elongase enzyme activities were similar $(\mathrm{P}>0.05)$ in the perirenal fat of bulls from four diets (Table 4).

Mean unsaturated (SFA, 63.3\%) and monounsaturated (MUFA, 34.2\%) did not changes among diets ( $\mathrm{P}>0.72$ and $\mathrm{P}>$ 0.49, respectively) (Table 4). However, diets with glycerin inclusion (GLYC and GLVO, diets) decrease (P < 0.01; -39\%) polyunsaturated fatty acid (PUFA), total n-6 $(\mathrm{P}<0.01 ;-51 \%)$ and total $n-3(\mathrm{P}<0.05 ;-8 \%)$ percentages in the perirenal fat in comparison of bulls finished in the CONT and VOIL diets.

The glycerin inclusion in the diets (GLYC and GLVO diets) decreased the PUFA:SFA ( $\mathrm{P}<0.03 ;-50 \%)$ and n-6:n-3 (P $<0.05 ;-39 \%$ ) ratios in the perirenal fat in comparison of perirenal fat of bulls finished with CONT and VOIL diets (Table 4). However, the PUFA:SFA and n-6:n-3 ratios were similar $(\mathrm{P}>0.05)$ between perirenal fat of bulls finished with CONT and VOIL diets and GLYC and GLVO diets.

\subsection{Fatty acid composition in the subcutaneous fat}

The lauric (0.03\%; P > 0.15), myristic (3.35\%; $\mathrm{P}>0.79)$, palmitic (26.8\%; $\mathrm{P}>0.80)$, stearic (15.2\%: $\mathrm{P}>0.07)$, docosanoic $(0.18 \% ; \mathrm{P}>0.44)$, tetradecenoic $(1.03 \% ; \mathrm{P}>0.17)$, palmitoleic $(4.73 \% ; \mathrm{P}>0.44)$, trans-vaccenic $(1.77 \% ; \mathrm{P}>0.46)$, oleic (39.4\%; P > 0.46), cis-vaccenic (1.16\%; P > 0.75), conjugated linoleic acid (0.11\%; P > 0.64), $\alpha$-linolenic $(0.10 \% ; \mathrm{P}>$ $0.29)$, arachidonic (1.03\%; $\mathrm{P}>0.21)$, eicosapentaenoic $(0.12 \% ; \mathrm{P}>0.16)$, docosapentaenoic $(0.11 \% ; \mathrm{P}>0.17)$ and docosahexaenoic $(\mathrm{P}>0.50)$ fatty acids percentages did not changes by diets in the subcutaneous fat (Table 5). 
Table 5. Fatty acid composition in the fat subcutaneous of Purunã bulls finished in feedlot.

\begin{tabular}{|c|c|c|c|c|c|c|}
\hline \multirow{2}{*}{ Fatty acids } & \multicolumn{4}{|c|}{ Treatments } & \multirow{2}{*}{$\mathrm{STD}^{5}$} & \multirow{2}{*}{$\mathrm{P}^{6}$} \\
\hline & $\mathrm{CONT}^{1}$ & VOIL $^{2}$ & GLYC $^{3}$ & $\mathrm{GLVO}^{4}$ & & \\
\hline 12:0, lauric & 0.03 & 0.04 & 0.03 & 0.03 & 0.01 & 0.15 \\
\hline 14:0, myristic & 3.24 & 3.39 & 3.52 & 3.26 & 0.10 & 0.79 \\
\hline 15:0, pentadecanoic & $0.51 \mathrm{~b}$ & $0.42 b$ & $0.65 \mathrm{a}$ & $0.69 \mathrm{a}$ & 0.03 & 0.01 \\
\hline 16:0, palmitic & 27.3 & 26.9 & 26.4 & 26.7 & 0.30 & 0.80 \\
\hline 17:0, margaric & $0.89 b$ & $0.80 \mathrm{~b}$ & $1.20 \mathrm{a}$ & $1.43 \mathrm{a}$ & 0.06 & 0.01 \\
\hline $18: 0$, stearic & 16.4 & 15.9 & 12.8 & 15.9 & 0.55 & 0.07 \\
\hline 22:0, docosanoic & 0.16 & 0.14 & 0.21 & 0.19 & 0.01 & 0.44 \\
\hline 14:1 n-7, 7-Tetradecenoic & 0.96 & 0.94 & 1.29 & 0.91 & 0.06 & 0.17 \\
\hline 15:1 n-9, pentadecanoic & $0.30 \mathrm{a}$ & $0.26 \mathrm{a}$ & $0.24 b$ & $0.22 b$ & 0.09 & 0.01 \\
\hline 16:1 n-9, palmitoleic & 4.69 & 4.63 & 5.21 & 4.37 & 0.18 & 0.44 \\
\hline 17:1 n-9, cis-10-heptadecaenoic & $0.71 b$ & $0.64 b$ & $1.15 \mathrm{a}$ & $1.19 \mathrm{a}$ & 0.07 & 0.03 \\
\hline 18:1 $n$-11t, trans-vaccenic & 1.81 & 1.90 & 1.51 & 1.85 & 0.12 & 0.46 \\
\hline 18:1 n-9c, oleic & 38.4 & 38.9 & 41.2 & 39.1 & 0.56 & 0.32 \\
\hline 18:1 n-7c, cis-vaccenic & 1.05 & 1.20 & 1.24 & 1.13 & 0.06 & 0.75 \\
\hline 18:2 n-6, linoleic - LA & $1.67 \mathrm{a}$ & $1.99 \mathrm{a}$ & $1.45 b$ & $1.23 \mathrm{~b}$ & 0.08 & 0.04 \\
\hline 18:2 c9, t11 - CLA & 0.11 & 0.11 & 0.12 & 0.10 & 0.05 & 0.64 \\
\hline $18: 3 n-6, \gamma$-linolenic & $0.16 b$ & $0.17 b$ & $0.20 \mathrm{a}$ & $0.16 b$ & 0.04 & 0.04 \\
\hline 18:3 $n$-3, $\alpha$-linolenic - LNA & 0.10 & 0.10 & 0.10 & 0.09 & 0.03 & 0.29 \\
\hline 20:4 n-6, arachidonic - AA & 1.03 & 1.02 & 1.03 & 1.03 & 0.01 & 0.21 \\
\hline 20:5 n-3, eicosapentaenoic - EPA & 0.12 & 0.13 & 0.12 & 0.12 & 0.01 & 0.16 \\
\hline 22:5 n-3, docosapentaenoic - DPA & 0.11 & 0.11 & 0.11 & 0.11 & 0.06 & 0.17 \\
\hline 22:6 n-3, docosahexaenoic - DHA & 0.12 & 0.13 & 0.12 & 0.14 & 0.08 & 0.50 \\
\hline \multicolumn{7}{|l|}{ Total fatty acid sum } \\
\hline Saturated, SFA & 48.5 & 47.7 & 44.8 & 48.3 & 0.73 & 0.25 \\
\hline Monounsaturated, MUFA & 48.1 & 48.5 & 51.8 & 48.6 & 0.73 & 0.22 \\
\hline Polyunsaturated, PUFA & $3.42 \mathrm{a}$ & $3.76 \mathrm{a}$ & $3.25 b$ & $3.00 \mathrm{~b}$ & 0.08 & 0.01 \\
\hline$n-6$, omega -6 & $2.86 \mathrm{a}$ & $3.18 \mathrm{a}$ & $2.67 b$ & $2.43 b$ & 0.08 & 0.05 \\
\hline$n-3$, omega -3 & 0.45 & 0.46 & 0.45 & 0.47 & 0.09 & 0.73 \\
\hline PUFA:SFA & 0.07 & 0.08 & 0.07 & 0.06 & 0.02 & 0.06 \\
\hline$n-6: n-3$ & $6.34 \mathrm{a}$ & $6.89 \mathrm{a}$ & $5.90 \mathrm{~b}$ & $5.22 b$ & 0.83 & 0.04 \\
\hline \multicolumn{7}{|l|}{ Enzymes activities } \\
\hline$\Delta 9$-desaturase $(16)^{\mathrm{A}}$ & 14.5 & 14.7 & 16.4 & 14.1 & 0.52 & 0.44 \\
\hline$\Delta 9$-desaturase $(18)^{\mathrm{B}}$ & 70.1 & 70.9 & 76.2 & 70.9 & 0.97 & 0.11 \\
\hline Elongase $^{\mathrm{C}}$ & 63.1 & 63.4 & 63.1 & 63.8 & 0.39 & 0.91 \\
\hline
\end{tabular}

${ }^{1} \mathrm{CONT}$ - Without glycerin or vegetable oils. ${ }^{2}$ VOIL - Vegetable oils. ${ }^{3}$ GILYC - Glycerin. ${ }^{4} \mathrm{GLVO}$ - Glycerin + vegetable oils. ${ }^{5}$ Standard deviation. ${ }^{6}$ Probability of Tukey test for treatment, $\mathrm{n}=8$ per treatment. ${ }^{\mathrm{A}} \Delta 9$-desaturase $(16)=$ index of desaturase enzyme activity in $\mathrm{C} 16$ fatty acids $=100\left(16: 1 \Delta^{9} / 16: 0+16: 1 \Delta^{9}\right) .{ }^{\mathrm{B}} \Delta 9$-desaturase $(16)=$ index of desaturase enzyme activity in C18 fatty acids $=100\left(18: 1 \Delta^{9} / 18: 0+\right.$ 18:1 $\left.\Delta^{9}\right)$. ${ }^{C}$ Index of elongase enzyme activity in the chain-lengthening of C16-C18 fatty acids $=100\left(18: 0+18: 1 \Delta^{9} / 16: 0+16: 1 \Delta^{9}+18: 0+\right.$ 18:1 $\left.\Delta^{9}\right)$. Total SFA sum of $(\mathrm{C} 12: 0+\mathrm{C} 13: 0+\mathrm{C} 14: 0+\mathrm{C} 15: 0+\mathrm{C} 16: 0+\mathrm{C} 17: 0+\mathrm{C} 18: 0+\mathrm{C} 20: 0+\mathrm{C} 21: 0+\mathrm{C} 22: 0)$. Total MUFA sum of $(\mathrm{C} 14: 1 n-7+\mathrm{C} 15: n-9+\mathrm{C} 16: 1 n-9+\mathrm{C} 16: 1 n-7+17: 1 n-9+\mathrm{C} 18: 1 n-11 \mathrm{t}+\mathrm{C} 18: 1 n-9 \mathrm{c}+\mathrm{C} 18: 1 n-7 \mathrm{c})$. Total $n-6$ sum of $(\mathrm{C} 18: 2 n-6+\mathrm{C} 18: 3 n-$ $6+\mathrm{C} 20: 4 n-6)$. Total $n-3$ sum of $(\mathrm{C} 18: 3 n-3+\mathrm{C} 20: 5 n-3+\mathrm{C} 22: 5 n-3+\mathrm{C} 22: 6 n-3)$.

Source: Authors.

The glycerin inclusion in the diets (GLYC and GLVO diets) increased the pentadecanoic (P < $0.01 ;+44 \%)$, margaric $(\mathrm{P}<0.01 ;+55 \%)$, and heptadecanoic $(\mathrm{P}<0.03 ;+73 \%)$ fatty acid percentage in the subcutaneous fat in comparison to bulls fed CONT and VOIL diets (Table 5). Still, the pentadecanoic, margaric and heptadecanoic fatty acid percentages were similar (P > 0.05) between subcutaneous fat of bulls finished with CONT and VOIL diets and GLYC and GLVO diets.

On the other hand, glycerin inclusion in the diets (GLYC and GLVO diets) decreased pentadecanoic $(\mathrm{P}<0.01 ;-22 \%)$, linoleic $(\mathrm{P}<0.04 ;-37 \%)$, and $\alpha$-linolenic $(\mathrm{P}<0.04 ;-9 \%)$. Still, the pentadecanoic, linoleic and $\alpha$-linolenic fatty acid percentages were similar $(\mathrm{P}>0.05)$ in the subcutaneous fat between bulls finished with CONT and VOIL diets and GLYC and GLVO diets. 
The $\Delta^{9}$-desaturase $(\mathrm{C} 16)$, The $\Delta^{9}$-desaturase $(\mathrm{C} 18)$ and elongase enzyme activities were similar $(\mathrm{P}>0.05)$ in the perirenal fat of bulls from four diets (Table 5).

The SFA (47.3\%; P > 0.25), MUFA (49.2\%; P > 0.22) and total n-3 (0.45\%; P > 0.73) acids levels did not change by diets (Table 5). On the other hand, glycerin inclusion in the diets decreased PUFA $(\mathrm{P}<0.01 ;-15 \%)$ and $\mathrm{n}-6(\mathrm{P}<0.05 ;-18 \%)$ fatty acids in comparison to CONT and VOIL diets (Table 5).

The PUFA:MUFA ratio in the fat subcutaneous did not change (P > 0.06) among diets (Table 5). However, the n-6:n-3 ratio was lower $(\mathrm{P}<0.04 ;-19 \%)$ in the fat subcutaneous of bulls fed glycerin inclusion in the diets in compassion of fat subcutaneous of bulls with CONT and VOIL diets. Still, the n-6:n-3 ratio were similar $(\mathrm{P}>0.05)$ between subcutaneous fat of bulls finished with CONT and VOIL diets and GLYC and GLVO diets.

\subsection{Fatty acid composition in the longissimus thoracis (lt) muscle}

Corn grains replacing by glycerin and vegetable oils in the diets of bulls finished in feedlot did not change the fat percentages in the LT muscle of lauric $(0.03 \%$; P > 0.16), myristic (2.63\%; P > 0.98), palmitic $(27.3 \%$; $\mathrm{P}>0.69)$, docosanoic $(0.13 \% \mathrm{P}>0.73)$, tetradecenoic $(0.48 \% ; \mathrm{P}>0.77)$, pentadecanoic $(0.16 \% ; \mathrm{P}>0.32)$, palmitoleic $(3.30 \% ; \mathrm{P}>0.33)$, cis-vaccenic $(1.14 \% ; \mathrm{P}>0.24)$, conjugated linoleic acid $(0.18 \% ; \mathrm{P}>0.18), \gamma$-linolenic $(0.11 \% ; \mathrm{P}>0.11)$, docosapentaenoic $(0.15 \% ; \mathrm{P}>0.44)$ and docosahexaenoic $(1.29 \% ; \mathrm{P}>0.38)$ fatty acids (Table 6$)$.

Table 6. Fatty acid composition in the Longissimus thoracis (LT) muscle of Purunã bulls finished in feedlot.

\begin{tabular}{|c|c|c|c|c|c|c|}
\hline \multirow{2}{*}{ Fatty acid } & \multicolumn{4}{|c|}{ Treatments } & \multirow{2}{*}{$\mathrm{STD}^{5}$} & \multirow{2}{*}{$\mathrm{P}^{6}$} \\
\hline & $\mathrm{CONT}^{1}$ & $\mathrm{VOIL}^{2}$ & GLYC $^{3}$ & $\mathrm{GLVO}^{4}$ & & \\
\hline 12:0, lauric & 0.03 & 0.03 & 0.03 & 0.03 & 0.01 & 0.16 \\
\hline 14:0, myristic & 2.60 & 2.69 & 2.60 & 2.66 & 0.10 & 0.98 \\
\hline 15:0, pentadecanoic & $0.32 b$ & $0.30 \mathrm{~b}$ & $0.50 \mathrm{a}$ & $0.44 \mathrm{a}$ & 0.02 & 0.01 \\
\hline 16:0, palmitic & 27.7 & 27.4 & 26.5 & 27.7 & 0.37 & 0.69 \\
\hline 17:0, margaric & $0.84 \mathrm{~b}$ & $0.77 b$ & $1.33 \mathrm{a}$ & $1.23 \mathrm{a}$ & 0.08 & 0.04 \\
\hline 18:0, stearic & $17.0 \mathrm{a}$ & $18.6 \mathrm{a}$ & $15.4 b$ & $16.1 b$ & 0.39 & 0.02 \\
\hline 22:0, docosanoic & 0.12 & 0.11 & 0.13 & 0.13 & 0.01 & 0.73 \\
\hline 14:1 n-7, 7-Tetradecenoic & 0.45 & 0.40 & 0.52 & 0.53 & 0.04 & 0.77 \\
\hline 15:1 n-9, pentadecanoic & 0.16 & 0.17 & 0.15 & 0.15 & 0.05 & 0.32 \\
\hline 16:1 $n-9$, palmitoleic & 3.16 & 2.91 & 3.43 & 3.72 & 0.16 & 0.33 \\
\hline 17:1 n-9, cis-10-heptadecaenoic & $0.56 \mathrm{~b}$ & $0.45 b$ & $1.01 \mathrm{a}$ & $0.89 \mathrm{a}$ & 0.06 & 0.02 \\
\hline 18:1 $n$-11t, trans-vaccenic & $1.26 \mathrm{~b}$ & $1.59 \mathrm{a}$ & $1.24 b$ & $1.64 \mathrm{a}$ & 0.07 & 0.09 \\
\hline 18:1n-9c, oleic & $37.1 \mathrm{a}$ & $34.8 b$ & $38.5 \mathrm{a}$ & $37.7 \mathrm{a}$ & 0.45 & 0.01 \\
\hline 18:1 n-7c, cis-vaccenic & 0.93 & 1.18 & 1.11 & 1.35 & 0.07 & 0.24 \\
\hline 18:2 n-6, linoleic - LA & $4.69 \mathrm{a}$ & $5.29 \mathrm{a}$ & $3.91 b$ & $2.71 b$ & 0.30 & 0.05 \\
\hline 18:2 c9, t11 - CLA & 0.18 & 0.17 & 0.18 & 0.18 & 0.01 & 0.18 \\
\hline 18:3 $n$-6, $\gamma$-linolenic & 0.11 & 0.11 & 0.12 & 0.11 & 0.03 & 0.11 \\
\hline 18:3 n-3, $\alpha$-linolenic - LNA & $0.17 \mathrm{a}$ & $0.18 \mathrm{a}$ & $0.17 \mathrm{a}$ & $0.13 b$ & 0.08 & 0.09 \\
\hline 20:4 n-6, arachidonic - AA & $1.11 \mathrm{~b}$ & $1.11 \mathrm{~b}$ & $1.19 \mathrm{a}$ & $1.18 \mathrm{a}$ & 0.03 & 0.05 \\
\hline 20:5 n-3, eicosapentaenoic - EPA & $0.15 \mathrm{a}$ & $0.15 \mathrm{a}$ & $0.12 b$ & $0.12 b$ & 0.03 & 0.01 \\
\hline $22: 5 n-3$, docosapentaenoic - DPA & 0.14 & 0.16 & 0.15 & 0.14 & 0.03 & 0.44 \\
\hline 22:6 n-3, docosahexaenoic - DHA & 1.18 & 1.34 & 1.59 & 1.04 & 0.11 & 0.38 \\
\hline \multicolumn{7}{|l|}{ Total fatty acid sum } \\
\hline Saturated, SFA & 48.8 & 50.1 & 46.7 & 48.4 & 0.48 & 0.09 \\
\hline Monounsaturated, MUFA & 43.5 & 41.4 & 45.9 & 46.1 & 0.57 & 0.07 \\
\hline Polyunsaturated, PUFA & 7.61 & 8.41 & 7.33 & 5.51 & 0.41 & 0.08 \\
\hline$n-6$, omega -6 & $5.90 \mathrm{a}$ & $6.51 \mathrm{a}$ & $5.21 \mathrm{~b}$ & $4.00 \mathrm{~b}$ & 0.30 & 0.02 \\
\hline$n-3$, omega -3 & 1.63 & 1.83 & 2.03 & 1.43 & 0.12 & 0.37 \\
\hline PUFA:SFA & 0.16 & 0.17 & 0.16 & 0.11 & 0.08 & 0.13 \\
\hline$n-6: n-3$ & 3.60 & 3.70 & 2.77 & 3.26 & 0.22 & 0.38 \\
\hline \multicolumn{7}{|l|}{ Enzyme activities } \\
\hline$\Delta 9$-desaturase $(16)^{\mathrm{A}}$ & 10.1 & 9.54 & 11.3 & 11.6 & 0.39 & 0.21 \\
\hline$\Delta 9$-desaturase $(18)^{\mathrm{B}}$ & $68.4 \mathrm{~b}$ & $65.1 \mathrm{~b}$ & $71.3 \mathrm{a}$ & $70.1 \mathrm{a}$ & 0.67 & 0.03 \\
\hline Elongase $^{\mathrm{C}}$ & 63.5 & 63.7 & 64.1 & 63.1 & 0.48 & 0.89 \\
\hline
\end{tabular}


${ }^{1}$ CONT - Without glycerin or vegetable oils. ${ }^{2}$ VOIL - Vegetable oils. ${ }^{3}$ GILYC - Glycerin. ${ }^{4}$ GLVO - Glycerin + vegetable oils. ${ }^{5}$ Standard deviation. ${ }^{6}$ Probability of Tukey test for treatment, $\mathrm{n}=8$ per treatment. ${ }^{\mathrm{A}} \Delta 9$-desaturase $(16)=$ index of desaturase enzyme activity in $\mathrm{C} 16$ fatty acids $=100\left(16: 1 \Delta^{9} / 16: 0+16: 1 \Delta^{9}\right) .{ }^{\mathrm{B}} \Delta$ 9-desaturase $(16)=$ index of desaturase enzyme activity in C18 fatty acids $=100\left(18: 1 \Delta^{9} / 18: 0+\right.$ 18:1 $\left.\Delta^{9}\right)$. ${ }^{\mathrm{C}}$ Index of elongase enzyme activity in the chain-lengthening of C16-C18 fatty acids $=100\left(18: 0+18: 1 \Delta^{9} / 16: 0+16: 1 \Delta^{9}+18: 0+\right.$ 18:1 $\left.\Delta^{9}\right)$. Total SFA sum of $(\mathrm{C} 12: 0+\mathrm{C} 13: 0+\mathrm{C} 14: 0+\mathrm{C} 15: 0+\mathrm{C} 16: 0+\mathrm{C} 17: 0+\mathrm{C} 18: 0+\mathrm{C} 20: 0+\mathrm{C} 21: 0+\mathrm{C} 22: 0)$. Total MUFA sum of $(\mathrm{C} 14: 1 n-7+\mathrm{C} 15: n-9+\mathrm{C} 16: 1 n-9+\mathrm{C} 16: 1 n-7+17: 1 n-9+\mathrm{C} 18: 1 n-11 \mathrm{t}+\mathrm{C} 18: 1 n-9 \mathrm{c}+\mathrm{C} 18: 1 n-7 \mathrm{c})$. Total $n-6$ sum of $(\mathrm{C} 18: 2 n-6+\mathrm{C} 18: 3 n-$ $6+\mathrm{C} 20: 4 n-6)$. Total $n-3$ sum of $(\mathrm{C} 18: 3 n-3+\mathrm{C} 20: 5 n-3+\mathrm{C} 22: 5 n-3+\mathrm{C} 22: 6 n-3)$.

Source: Authors.

The glycerin inclusion in the diets (GLYC and GLVO diets) increased the pentadecanoic $(\mathrm{P}<0.01 ;+52 \%)$, margaric ( $\mathrm{P}<0.04 ;+59 \%)$, heptadecanoic $(\mathrm{P}<0.01 ;+88 \%)$, oleic $(\mathrm{P}<0.01 ;+6 \%)$ and arachidonic $(\mathrm{P}<0.05 ;+72 \%)$ fatty acid percentage in the LT muscle in comparison to bulls fed CONT and VOIL diets (Table 5). Still, the pentadecanoic, margaric, heptadecanoic, oleic and arachidonic fatty acid percentages were similar $(\mathrm{P}>0.05)$ between LT muscle of bulls finished with CONT and VOIL diets and GLYC and GLVO diets.

The $\Delta^{9}$-desaturase $(\mathrm{C} 16)$ and elongase enzyme activities were similar $(\mathrm{P}>0.05)$ in the LT muscle of bulls finished with four diets (Table 6). However, the $\Delta^{9}$-desaturase (C18) enzyme activity in the LT muscle was higher $(\mathrm{P}<0.03)$ in the LT muscle of bulls finished of glycerin inclusion (GLYC and GLVO diets) in comparison of CONT and VOIL diets (Table 6). Still, the $\Delta^{9}-$ desaturase (C18) value was similar (P > 0.05) between LT muscle of bulls finished with CONT and VOIL diets and GLYC and GLVO diets.

The saturated $(\mathrm{P}>0.09)$, monounsaturated $(\mathrm{P}>0.07)$, polyunsaturated $(\mathrm{P}>0.08)$ and $n-3$ percentages $(\mathrm{P}>0.37)$ fatty acids were similar among (Table 6). Similarly, the PUFA:SFA and n-6:n-3 fatty acids ratios were similar among four diets (Table 6). However, the glycerin inclusion in the diets (GLYC and GLVO diets) decreased (P $<0.02 ;+35 \%$ ) the n- 6 fatty acid percentage in comparison to CONT and VOIL diets (Table 6).

\section{Discussion}

The experimental design allowed a young bull's production and examination of corn grain replaced by glycerin as energy source and vegetal oils as natural compounds on fatty acids composition in the perineal and subcutaneous fat and Longissimus thoracis (LT) muscle. At the beginning of the experiment, it was observed changes in fatty acid percentage in the diets when replaced corn grain by glycerin (Table 3). Diets with glycerin decrease SFA (13.2\%), MUFA (26.1\%) and PUFA $(20.2 \%)$.

The bulls were slaughter 20 month's age and a finishing period 252 days in feedlot. In contrast, feedlot practices in Brazil usually range 24 to 28 months and period about 4 months (Françozo et al., 2013; Zawadzki et al., 2011). Previous studies reported meat fatty acid composition is influenced by genetic groups (Rotta et al., 2009) and dietary factors (Padre et al., 2006, 2007; Smet et al., 2004). According, De Smet et al. (2004) the percentages of SFA and MUFA content increases faster with increasing fatness than does the content of PUFA. Thus, it was selected animals of same genetic group (1/4 Aberdeen Angus $+1 / 4$ Caracu $+1 / 4$ Charolais $+1 / 4$ Canchim) to reduce the effect hereditary on fat deposition.

Manipulation of fatty acids composition through feeding is usually more practical and cost effective compared to new breeding strategies. Fat deposition occurs at different stages of growth, which is observed greats rate of deposition in internal fat followed intramuscular, subcutaneous and intramuscular. Previous study (Eiras et al., 2014b; Françozo et al., 2013; Prado et al., 2016; Silva et al., 2017) report increased intramuscular fat and fat thickness, whereas any effect on total lipids in the LT in response to glycerin and vegetal oils inclusion in the diets.

The free glycerol in the blood stream is metabolized in the liver to glycerol-3-phosphate by glycerol kinase enzyme, which is used to triacylglycerol and phospholipids synthesis. According De Smet et al. (2004) the phospholipids content is independent of the total fat content while triacylglycerol is strongly correlated with the total fat content. Likewise, Aldai et al. 
(2007) reported that intramuscular fat constituted the most homogenous adipose tissue in response different genotypes. In general, ruminant meat contains higher percentage of 16:0 and 18:0 fatty acids (Aricetti et al., 2008; Ducatti et al., 2009; Prado et al., 2003).

\subsection{Perirenal fat}

In the total sum of saturated fatty acids (SFA) there was no effect of glycerin and vegetable oils inclusion in the diets in the perirenal fatty acid percentage, although the total sum of saturated fatty acids was high (63\%). Similarly, the glycerin and vegetable oils inclusion in the diets of bulls finished in feedlot had little influence on individual saturated fatty acids percentage in the perirenal fat, except for the increase of margaric fatty acid and reduction of stearic fatty acid. The reduction of stearic acid in the perirenal fat probably occurs due lower proportion of total fatty acid in diets with glycerin (Table3).

As observed to saturated fatty acids, in the total sum of monounsaturated fatty acids there was no effect of glycerin and vegetable oils inclusion in the diets in the perirenal fatty acid percentage. However, the MUFA was low (34\%) when compared with MUFA percentage in the subcutaneous fat and Longissimus muscle from the same animals. However, the glycerin and vegetable oils inclusion in the diets increased cis-10-heptadecaenoic fatty acid and decreased pentadecanoic fatty acid in the perirenal fat. Thus, the glycerin and vegetable oils inclusion in the diets had small meaning on MUFA in the perirenal fat of bulls. The lower percentage of MUFA in the perirenal fat probably is due higher metabolizing of glycerol to triacylglycerol. However, in currently study no was determined phospholipids and triacylglycerol content in the perirenal fat. The triacylglycerol contains much lower amounts of MUFA, whereas are rich in PUFA (Smet et al., 2004) due phospholipids as constituents of the cell membrane.

On the other hand, the glycerin and vegetable oils inclusion in the diets (GLYC and GLVO diets) decreased polyunsaturated fatty acid (PUFA) percentage in the perirenal adipose tissue of bulls in comparison to CONT and VOIL diets due to the lower percentage of the individual polyunsaturated fatty acids linoleic and $\alpha$-linolenic.

The PUFA:MUFA and $n-6: n-3$ ratios in the perirenal adipose tissue of bulls were lower with glycerin and vegetable oils inclusion in the diets in comparison to CONT and VOIL diets due to the lower percentage of the PUFA and $n-6$ fatty acids. The reduction of PUFA, total $n-6$ and $n-3$, PUFA:SFA and $n-6: n-3$ ratios can be explained by fatty acids content in diets (Table 3).

The glycerin and vegetable oils inclusion in the diets decreased $n-6$ and $n-3$ fatty acids percentage in the perirenal adipose tissue of bulls in comparison to CONT and VOIL diets.

On the other hand, we observed higher $\Delta^{9}$-desaturase enzyme (C18) activity in diets with glycerin and lower activity in CONT and VOIL diets. The $\Delta^{9}$-desaturase convert stearic fatty acid into the $n$-9 monounsaturated fatty acid oleic (Malau-Aduli et al., 1997).

However, we observed increase of elongase enzyme activity in VOIL diet and decreased in GLVO diet (Table 4). The levels of stearic acid on perirenal fat can be explained by elongase enzyme activity (Table 4).

\subsection{Fatty acid in the subcutaneous fat}

The diversity of fatty acids in the subcutaneous fat is partly explained by biohydrogenation reactions in the rumen (Benchaar et al., 2001; Tamminga \& Doreau, 1991). In the total sum of saturated fatty acids there was no effect of glycerin and vegetable oils inclusion in the diets on fatty acid percentage in the subcutaneous fat. Similarly, the glycerin and vegetable oils inclusion in the diets of bulls finished in feedlot had little influence on individual saturated fatty acids percentage in the subcutaneous fat, except for the increase of pentadecanoic and margaric fatty acid. According Zock et al. (1994) lauric, myristic and palmitic fatty acid increase serum total cholesterol and low-density lipoprotein levels, whereas stearic, oleic and linoleic 
fatty acids decrease serum total cholesterol and low-density lipoprotein levels. Carvalho et al. (2014) did not observe changing in saturated fatty acids when the glycerin was included up to $18 \%$ in the diets of young bulls finished in feedlot.

As observed to saturated fatty acids, in the total sum of monounsaturated fatty acids there was no effect of glycerin and vegetable oils inclusion in the diets of fat fatty acid percentage in the subcutaneous fat. Similarly, the glycerin and vegetable oils inclusion in the diets of bulls finished in feedlot had little influence on individual monounsaturated fatty acids percentage in the subcutaneous fat, except for the reduce of pentadecanoic and the increase of heptadecanoic fatty acid. Carvalho et al. (2014) did not observe changing in monounsaturated fatty acids when the glycerin was included up to $18 \%$ in the diets of young bulls finished in feedlot.

On the other hand, the glycerin and vegetable oils inclusion in the diets (GLYC and GLVO diets) decreased monounsaturated fatty acid percentage in the perirenal adipose tissue of bulls in comparison to CONT and VOIL diets due to the lower percentage of the individual polyunsaturated fatty acids linoleic.

Previous study reported elongase enzyme activity on 16:0 to 18:0 (Malau-Aduli et al., 1997). However, any difference was observed on 16:0 and elongase activity both tissues (Table 6 and 7). On the other hand, diets with glycerin (GLY and GOL) increase 18:1 $n$-9 on LT (Table 6). These results on LT can be explained by results obtained in $\Delta^{9}$-desaturase (18) enzyme activity (Table 6), which is important enzyme in the synthesis of monounsaturated fatty acids in bovine tissue (Chang et al., 1992). In contrast, Eiras et al. (2014b) reported any difference on C18:1 $n$-9 acid in the LT in response glycerin levels.

The glycerin and vegetable oils inclusion in the diets decreased $n-6$ and did not effect on $n-3$ fatty acid percentage in the subcutaneous fat of bulls in comparison to CONT and VOIL diets.

The PUFA:MUFA ratio in the fat subcutaneous of bulls were similar and n-6:n-3 ratio was lower with glycerin and vegetable oils inclusion in the diets in comparison to CONT and VOIL diets due to the lower percentage of the PUFA and $n-6$ fatty acids. The reduction of PUFA, total $n-6$ and $n-3$, PUFA:SFA and $n-6: n-3$ ratios can be explained by fatty acids content in diets (Table 3).

\subsection{Fatty acid in the Longissimus thoracis (Lt) muscle}

Total sum saturated fatty acids (SFA) in the LT muscle were showed in Table 6. The percentage of SFA was similar in the LT muscle among four diets. Thus, the glycerin and vegetable oils addition in the diets did not alter the SFA in LT muscle as observed by Françozo et al. (2013), Prado et al. (2016) and Silva et al. (2017) in the LT muscle from animals finished to up $18 \%$ of glycerin in the diets. However, other authors (Carvalho et al., 2014; Eiras et al., 2014) observed a reduction of SFA in the LM muscle of bulls finished in feedlot and fed with glycerin addition in the diets. On the other hand, the glycerin + vegetable oils in the diets increased the pentadecanoic and margaric fatty acids and decreased the stearic fatty acid.

As observed to SFA, the glycerin and vegetable oils in the diets did not alter the monounsaturated fatty acids (MUFA) in the LT muscle of bulls. Thus, the glycerin addition in the diets did not alter the SFA as observed by Françozo et al. (2013), Prado et al. (2016) and Silva et al. (2017) in the LT muscle from animals finished to up 18\% of glycerin in the diets. However, other authors (Carvalho et al., 2014; Eiras et al., 2014) observed a reduction of SFA in the LM muscle of bulls finished in feedlot and fed with glycerin addition in the diets. On the other hand, the glycerin + vegetable oils in the diets increased the heptadecanoic and oleic fatty acids and decreased the trans-vaccenic fatty acid. In general, these fatty acids have low concentration in LT (Padre et al., 2006, 2007). Previous study reported 18:1 n-9 most prominent MUFA occurring mainly as cis and trans isomers. The levels of trans-vaccenic fatty acid increase when vegetable oil was added in glycerin diet in the LT. Previous studies reported trans-vaccenic fatty acid as an important intermediate produced by microorganisms in the biohydrogenation of fatty acids in the rumen, which is precursor of CLA (Griinari \& Bauman, 1999). Likewise, other study showed beneficial health effects of CLA in humans. 
The observed increase in fatty acids such as pentadecanoic (C15:0), margaric (C17:0), and heptadecanoic (C17:1) acids is of interest for human health, because these lipids of microbial origin inhibit the growth of cancer cells. Glycerin increases ruminal propionate content and may promote the production of odd-chain fatty acids. Other authors found an increase in margaric acid concentration in meat from grazing cattle when animals received supplementary crude glycerin (San Vito et al., 2015).

This increase may be due to a higher amount of margaric acid with increase glycerin concentration in the diet (Table 3). A similar result was found by Lage et al. (2014), who reported an increase in the concentration of margaric acid when $10 \%$ glycerol was included in the diet of Nellore cattle finished in feedlots. Margaric acid does not have a high impact on serum cholesterol levels, as lauric (C12:0) and myristic (C14:0) saturated fatty acids; thus, increasing the margaric acid in meat does not cause risks to human health.

The total sum of polyunsaturated fatty acids (PUFA) was similar when the glycerin and vegetable oils were included in the diets. However, the glycerin and vegetable oils inclusion in the diets reduced linoleic, arachidonic and eicosapentaenoic fat acids in the LT muscle. Still, the glycerin and vegetable oils only did not affect the CLA, $\gamma$-linolenic, DPA and DHA fatty acids percentages, but the glycerin and vegetable oils addition together (GLVO diet) reduced the $\alpha$-linolenic fatty acid percentage. Diets in presents study contain high values of LA and LNA fatty acid (Table 3); however, these fatty acids are intensively bio hydrogenated by microorganisms to stearic fatty acid in the rumen (Griinari \& Bauman, 1999). Previous studies with different compounds extract by plants reported modification on ruminal fermentation (Yang et al. 2010). On the other hand, previous studies reported LA and LNA as essential in human diet; which are elongated and desaturated to long-chain PUFA's, to DHA, AA and EPA (Spector, 1999). Results in currently study showed higher levels of AA in diets with glycerin and higher levels of EPA in CONT and VOIL diets on LT, whereas DHA any difference was observed. However, these values are below adequate diet. According HMSO the recommended daily intake of EPA and DHA for adults ranges between 200 to $680 \mathrm{mg} / \mathrm{d}$ in several countries. These fatty acids are important to maintain cell membrane structure and physiological function.

Likewise, we observed higher values for total $n-6$ in diets without glycerin and vegetable oils (CONT and VOIL diets). However, the $n$ - 3 fatty acid was similar among four diets. Thus, the glycerin and vegetable oils addition decreased the $n-6$ fatty acid percentage and maintain the $n-3$ fatty acid percentage. Likewise, Aldai et al. (2007) reported similar values for $n-6: n-3$ ratio in LT muscle.

Results in currently study showed lower values of PUFA:SFA ratio (0.15) and higher levels of $n-6: n-3$ (3.33) ratio in LT muscle. However, PUFA:SFA ratio is below an adequate diet. On the other hand, $n-6: n-3$ ratio is adequate for consumption human. According HMSO (1994), the PUFA:SFA ratio should be above 0.45 and $n-6: n-3$ ratio lower than 4.0. Likewise results indicate that fatty acids essentials in human diet were observed for diets without glycerin (LA) and VOIL diet (LNA) on LT. The diversity of fatty acids in the LT muscle is partly explained by biohydrogenation reactions in the rumen (Benchaar et al., 2001; Tamminga \& Doreau, 1991).

Any difference was observed on $\Delta^{9}$-desaturase (16) and elongase activities in the LT muscle tissues. However, the $\Delta^{9}$ desaturase (18) was increased by diets with glycerin and vegetable inclusion (GLY and VOIL diets). These results on LT can be explained by results obtained in $\Delta^{9}$-desaturase (18) enzyme activity (Table 6), which is important enzyme in the synthesis of monounsaturated fatty acids in bovine tissue (Chang et al., 1992). In contrast, Eiras et al. (2014b) reported any difference on C18:1 $n-9$ acid in the LT in response glycerin levels.

\section{Conclusion}

Corn grain replacement by glycerin with $81.2 \%$ of glycerol might be fed to finishing bulls in feedlot change fatty acid composition on fat perirenal, Longissimus thoracis muscle and fat thickness. The glycerin inclusion reduces the levels of SFA, MUFA and PUFA in total diet. Diets did not change lauric, myristic and palmitic in Longissimus thoracis muscle and fat 
subcutaneous. On the other hand, diets with glycerin reduce levels of stearic acid on perirenal fat, Longissimus thoracis muscle and fat thickness. Likewise, levels of linoleic acid reduce with glycerin inclusion on perirenal fat, Longissimus thoracis muscle and fat thickness. Diets without glycerin or with FO improve linoleic, $\alpha$-linolenic and eicosapentaenoic acids on Longissimus thoracis muscle and fat thickness. Total PUFA, $n-6$ and PUFA:SFA and $n-6: n-3$ ratio improves with FO addition on fat thickness. Diets without glycerin and vegetable higher levels of SFA, PUFA and $n-6$ on Longissimus thoracis muscle. In general diets FO addition or no in diets without glycerin improve fatty acids on all tissues.

\section{Acknowledgements}

Current project was funded by the Araucaria Foundation, fund of the state of Paraná and the Brazilian Council for Research and Technological Development (CNPq). The authors would like to thank Processing Inc. (Biopar Bioenergia do Paraná, Rolândia PR Brazil) in providing of the glycerin and (Oligo Basics Agroindustrial Ltda., Cascavel, Paraná, Brazil) in providing financial resource, castor oil and cashew nut sell liquid, used in the research. Trade names or commercial products in this publication are mentioned solely for the purpose of providing specific information and do not imply recommendations or endorsement by the Department of Animal Science, State University of Maringá.

\section{Conflict of interest statement}

The authors declare no conflicts of interest.

\section{References}

Aldai, N., Nájera, A. I., Dugan, M. E. R., Celaya, R., \& Osoro, K. (2007). Characterisation of intramuscular, intermuscular and subcutaneous adipose tissues in yearling bulls of different genetic groups. Meat Science, 76(4), 682-691. https://doi.org/http://dx.doi.org/10.1016/j.meatsci.2007.02.008

Aricetti, J. A., Rotta, P. P., Prado, R. M., Perotto, D., Moletta, J. L., Matsushita, M., \& Prado, I. N. (2008). Carcass characteristics, chemical composition and fatty acid profile of Longissimus muscle of bulls and steers finished in a pasture system. Asian-Australasian Journal of Animal Sciences, 21(10), 1441-1448. https://doi.org/10.1590/S1516-35982012000200022.

Benchaar, C., Calsamiglia, S., Chaves, A. V., Fraser, G. R., Colombatto, D., McAllister, T. A., \& Beauchemin, K. A. (2008). A review of plant-derived essential oils in ruminant nutrition and production. Animal Feed Science and Technology. https://doi.org/10.1016/j.anifeedsci.2007.04.014

Benchaar, C., Chaves, A. V, Fraser, G. R., Wang, Y., Beauchemin, K. A., \& McAllister, T. A. (2007). Effects of essential oils and their components on in vitro rumen microbial fermentation. Canadian Journal of Animal Science, 87(3), 413-419.

Benchaar, C., Pomar, C., \& Chiquette, J. (2001). Evaluation of dietary strategies to reduce methane production in ruminants: A modelling approach. Canadian Journal of Animal Science, 81(4), 563-574. https://doi.org/http://dix.doi.org/10.4141/A00-119.

Carvalho, J. R. R., Chizzotti, M. L., Ramos, E. M., Machado Neto, O. R., Lanna, D. P. D., Lopes, L. S., Teixeira, P. D., \& Ladeira, M. M. (2014). Qualitative characteristics of meat from young bulls fed different levels of crude glycerin. Meat Science, 96(2, Part A), $977-983$.

https://doi.org/http://dx.doi.org/10.1016/j.meatsci.2013.10.020

Castagnino, P. S., Fiorentini, G., Dallantonia, E. E., San Vito, E., Messana, J. D., Torrecilhas, J. A., Sobrinho, A. G. S., \& Berchielli, T. T. (2018). Fatty acid profile and carcass traits of feedlot Nellore cattle fed crude glycerin and virginiamycin. Meat Science, 140, 51-58.

https://doi.org/10.1016/j.meatsci.2018.02.013.

Chang, J. H. P., Lunt, D. K., \& Smith, S. B. (1992). Fatty acid composition and fatty acid elongase and stearoyl-CoA desaturase activities in tissues of steers fed high oleate sunflower seed. The Journal of Nutrition, 122(11), 2074-2080.

CIOMS/OMS. (1985). Council for International Organizations of Medical Services. In International Guiding Principles for Biomedical Research Involving Animals. WHO Distribution and sales service.

Cruz, O. T. B., Valero, M. V., Zawadzki, F., Rivaroli, D. C., Prado, R. M., Lima, B. S., \& Prado, I. N. (2014). Effect of glycerine and essential oils (Anacardium occidentale and Ricinus communis) on animal performance, feed efficiency and carcass characteristics of crossbred bulls finished in a feedlot system. Italian Journal of Animal Science, 13(4), 3492.

Ducatti, T., Prado, I. N., Rotta, P. P., Prado, R. M., Perotto, D., Maggioni, D., \& Visentainer, J. V. (2009). Chemical composition and fatty acid profile in crossbred (bos taurus vs. Bos indicus) young bulls finished in a feedlot. Asian-Australasian Journal of Animal Sciences, 22 (3), $433-439$. https://doi.org/10.5713/ajas.2009.80255.

Eiras, C. E., Barbosa, L. P., Marques, J. A., Araújo, F. L., Lima, B. S., Zawadzki, F., Perotto, D., \& Prado, I. N. (2014). Glycerine levels in the diets of crossbred bulls finished in feedlot: Apparent digestibility, feed intake and animal performance. Animal Feed Science and Technology, 197. 
https://doi.org/10.1016/j.anifeedsci.2014.07.004.

Eiras, C. E., Guerrero, A., Valero, M. V, Pardo, J. A., Ornaghi, M. G., Rivaroli, D. C., Sañudo, C., \& Prado, I. N. (2017). Effects of cottonseed hulls levels in the diet and aging time on visual and sensory meat acceptability from young bulls finished in feedlot. Animal, 11(3), 529-537. https://doi.org/10.1017/S1751731116001749.

Eiras, C. E., Marques, J. A., Prado, R. M., Valero, M. V, Bonafé, E. G., Zawadzki, F., Perotto, D., \& Prado, I. N. (2014). Glycerin levels in the diets of crossbred bulls finished in feedlot: Carcass characteristics and meat quality. Meat Science, 96(2), 930-936. https://doi.org/10.1016/j.meatsci.2013.10.002.

Françozo, M. C., Prado, I. N., Cecato, U., Valero, M. V., Zawadzki, F., Ribeiro, O. L., Prado, R. M., \& Visentainer, J. V. (2013). Growth performance, carcass characteristics and meat quality of finishing bulls fed crude glycerin- supplemented diets. Brazilian Archives of Biology and Technology, 56(2). https://doi.org/10.1590/S1516-89132013000200019

Griinari, J. M., \& Bauman, D. E. (1999). Biosynthesis of conjugated linoleic acid and its incorporation into meat and milk in ruminants. Advances in Conjugated Linoleic Acid Research, 1(1), 180-200.

Guerrero, A., Rivaroli, D. C., Sañudo, C., Campo, M. M., Valero, M. V., Jorge, A. M., \& Prado, I. N. (2018). Consumer acceptability of beef from two sexes supplemented with essential oil mix. Animal Production Science, 58(9). https://doi.org/10.1071/AN15306.

HMSO. (1994). England Department of Health Nutritional. Aspects of cardiovascular disease. Report on Health and Social Subjects, 46, 37-46.

Kubo, J., Lee, J. R., \& Kubo, I. (1999). Anti-Helicobacter pylori Agents from the Cashew Apple. Journal of Agricultural and Food Chemistry, 47(2), 533537. https://doi.org/10.1021/jf9808980

Lage, J. F., Paulino, P. V. R., Pereira, L. G. R., Duarte, M. S., Valadares Filho, S. C., Oliveira, A. S., Souza, N. K. P., \& Lima, J. C. M. (2014). Carcass characteristics of feedlot lambs fed crude glycerin contaminated with high concentrations of crude fat. Meat Science, 96(1), 108-113. https://doi.org/http://dx.doi.org/10.1016/j.meatsci.2013.06.020

Malau-Aduli, A. E. O., Siebert, B. D., Bottema, C. D. K., \& Pitchford, W. S. (1997). A comparison of the fatty acid composition of triacylglycerols in adipose tissue from Limousin and Jersey cattle. Australian Journal of Agricultural Research, 48(5), 715-722.

Monteschio, J. O., Souza, K. A., Vital, A. A. C. P., Guerrero, A., Valero, M. V, Kempinski, E. M. B. C., Barcelos, V. C., Nascimento, K. F., \& Prado, I. N. (2017). Clove and rosemary essential oils and encapsuled active principles (eugenol, thymol and vanillin blend) on meat quality of feedlot-finished heifers. Meat Science, 130, 50-57. https://doi.org/10.1016/j.meatsci.2017.04.002.

Padre, R. G., Aricetti, J. A., Gomes, S. T. M., Goes, R. H. T. B., Moreira, F. B., Prado, I. N., Visentainer, J. V., Souza, N. E., \& Matsushita, M. (2007). Analysis of fatty acids in Longissimus muscle of steers of different genetic breeds finished in pasture systems. Livestock Science, 110(1-2), 57-63. https://doi.org/10.1016/j.livsci.2006.10.004

Padre, R. G., Aricetti, J. A., Moreira, F. B., Mizubuti, I. Y., Prado, I. N., Visentainer, J. V., Souza, N. E., \& Matsushita, M. (2006). Fatty acid profile, and chemical composition of Longissimus muscle of bovine steers and bulls finished in pasture system. Meat Science, 74(2), 242-248.

https://doi.org/10.1016/j.meatsci.2006.02.012

Prado, I. N., Cruz, O. T. B., Valero, M. V., Zawadzki, F., Eiras, C. E., Rivaroli, D. C., Prado, R. M., \& Visentainer, J. V. (2016). Effects of glycerin and essential oils (Anacardium occidentale and Ricinus communis) on the meat quality of crossbred bulls finished in a feedlot. Animal Production Science, 56(12), 2105-2114. https://doi.org/10.1071/AN14661.

Prado, I. N., Moreira, F. B., Matsushita, M., \& Souza, N. E. (2003). Longissimus dorsi fatty acids composition of Bos indicus and Bos indicus x Bos taurus crossbred steers finished in pasture. Brazilian Archives of Biology and Technology, 46(4), 601-608.

Prado, I. N., Oliveira, A. N., Rotta, P. P., Perotto, D., Prado, R. M., Silva, R. R., Souza, N. E., \& Moletta, J. L. (2009). Chemical and fatty acid composition of Longissimus muscle of crossbred bulls finished in feedlot. Asian-Australasian Journal of Animal Sciences, 22(7), 1054-1059. https://doi.org/10.5713/ajas.2009.80533.

Prado, I. N., Prado, R. M., Rotta, P. P., Visantainer, J. V, Moletta, J. L., \& Perotto, D. (2008). Carcass characteristics and chemical composition of the Longissimus muscle of crossbred bulls (Bos taurus indicus vs Bos taurus taurus) finished in feedlot. Journal of Animal and Feed Sciences, 17(3). https://doi.org/10.22358/jafs/66609/2008

Rotta, P. P., Prado, R. M., Prado, I. N., Valero, M. V., Visentainer, J. V., \& Silva, R. R. (2009). The effects of genetic groups, nutrition, finishing systems and gender of Brazilian cattle on carcass characteristics and beef composition and appearance: A review. Asian-Australasian Journal of Animal Sciences, 22(12), 1718-1734. https://doi.org/10.5713/ajas.2009.90071.

San Vito, E., Lage, J. F., Ribeiro, A. F., Silva, R. A., \& Berchielli, T. T. (2015). Fatty acid profile, carcass and quality traits of meat from Nellore young bulls on pasture supplemented with crude glycerin. Meat Science, 100, 17-23. https://doi.org/http://dx.doi.org/10.1016/j.meatsci.2014.09.008.

Silva, R. R., Carvalho, G. G. P., Silva, F. F., Prado, R. M., \& Carvalho, B. M. A. (2010). Meat quality of heifers finished on pasture with tropical grass and supplemented with glycerin. Ciencia e Investigación Agraria, 44(3), 320-332. https://doi.org/10.7764/rcia.v44i3.1861

Smet, S., Raes, K., \& Demeyer, D. (2004). Meat fatty acid composition as affected by fatness and genetic factors: a review. Animal Research, 53(2), 81-98. https://doi.org/10.1051/animres:2004003

Spector, A. A. (1999). Essentiality of fatty acids. Lipids, 34(1), S1--S3. https://doi.org/doi: 10.1007/BF02562220

Tamminga, S., \& Doreau, M. (1991). Lipids and rumen digestion. In J. P. Jouany (Ed.), Rumen microbial metabolism and ruminant digestion (Issue INRA Editions, pp. 151-164). Institut National de la Recherche Agronomique. 
Research, Society and Development, v. 10, n. 13, e66101319844, 2021

(CC BY 4.0) | ISSN 2525-3409 | DOI: http://dx.doi.org/10.33448/rsd-v10i13.19844

Ultee, A., Kets, E. P. W., Alberda, M., Hoekstra, F. A., \& Smid, E. J. (2000). Adaptation of the food-borne pathogen Bacillus cereus to carvacrol. Archives of Microbiology, 174(4), 233-238. https://doi.org/10.1007/s002030000199

Valero, M. V., Torrecilhas, J. A., Zawadzki, F., Bonafé, E. G., Madrona, G. S., Prado, R. M., Passetti, R. A. C., Rivaroli, D. C., Visentainer, J. V., \& Prado, I. N. (2014). Propolis or cashew and castor oils effects on composition of Longissimus muscle of crossbred bulls finished in feedlot. Chilean Journal of Agricultural Research, 74(4), 445-451. https://doi.org/10.4067/S0718-58392014000400011

Valero, M. V, Farias, M. S., Zawadzki, F., Prado, R. M., Fugita, C. A., Rivaroli, D. C., Ornaghi, M., \& Prado, I. N. (2016). Feeding propolis or functional oils (cashew and castor oils) to bulls: performance, digestibility and blood cells counts. Revista Colombiana de Ciencias Pecuarias, 29, 33-42. https://doi.org//10.17533/udea.rccp.v29n1a04.

Vital, A. C. P., Guerrero, A., Kempinski, E. M. B. C., Oliveira Monteschio, J., Sary, C., Ramos, T. R., del Mar Campo, M., \& Prado, I. N. (2018). Consumer profile and acceptability of cooked beef steaks with edible and active coating containing oregano and rosemary essential oils. Meat Science, 143, 153-158.

Wu, Z., \& Palmquist, D. L. (1991). Synthesis and biohydrogenation of fatty acids by ruminal microorganisms in vitro. Journal of Dairy Science, 74(9), 30353046.

Yang, W. Z., Benchaar, C., Ametaj, B. N., \& Beauchemin, K. A. (2010). Dose response to eugenol supplementation in growing beef cattle: Ruminal fermentation and intestinal digestion. Animal Feed Science and Technology, 158(1-2), 57-64. https://doi.org/10.1016/j.anifeedsci.2010.03.019

Zawadzki, F., Prado, I. N., Marques, J. A., Zeoula, L. M., Rotta, P. P., Sestari, B. B., Valero, M. V., \& Rivaroli, D. C. (2011). Sodium monensin or propolis extract in the diets of feedlot-finished bulls: Effects on animal performance and carcass characteristics. Journal of Animal and Feed Sciences, $20(1), 16-25$. https://doi.org/10.22358/jafs/66153/201

Zock, P. L., Vries, J. H., \& Katan, M. B. (1994). Impact of myristic acid versus palmitic acid on serum lipid and lipoprotein levels in healthy women and men. Arteriosclerosis and Thrombosis: A Journal of Vascular Biology, 14(4), 567-575. https://doi.org/10.1161/01.ATV.14.4.567 